\title{
Mephedrone (4-methylmethcathinone) and intracranial self- stimulation in C57BL/6J mice: comparison to cocaine
}

\author{
J. Elliott Robinson a,b,c, Abigail E. Agogliab,c, Eric W. Fish ${ }^{a, c}$, Michael C. Krouse ${ }^{a, c}$, and C. J. \\ Malanga, M.D., Ph.D. ${ }^{a, b, c}$ \\ a Department of Neurology, University of North Carolina at Chapel Hill, Chapel Hill, NC USA \\ b Curriculum in Neurobiology, University of North Carolina at Chapel Hill, Chapel Hill, NC USA \\ ${ }^{c}$ Bowles Center for Alcohol Studies, University of North Carolina at Chapel Hill, Chapel Hill, NC \\ USA
}

\section{INTRODUCTION}

Recreational use of cathinone-derived synthetic stimulants, more commonly known as "bath salts", has increased in prevalence during the last five years. Of these, mephedrone (4methylmethcathinone or "meow-meow") is popular among recreational users, most likely due to its availability and ability to elevate mood and produce euphoria [1]. Mephedrone use is associated with several stimulant-like drug effects, including increased concentration, talkativeness, psychomotor stimulation, reduced appetite, and insomnia [1]. Recent studies have described compulsive drug taking [2], and several deaths have been attributed to mephedrone use [3]. Not surprisingly, several countries, including the United States, have recently banned the production, possession, and sale of mephedrone and other cathinone derivatives [4].

Activation of mesocorticolimbic dopamine circuits is a common effect of drugs of abuse, and these circuits play a critical role in motivated behaviors, drug reinforcement, and drug seeking [5]. The effects of drugs of abuse on these circuits can be modeled in laboratory animals using several behavioral conditioning techniques, including intracranial selfstimulation (ICSS) [6, 7]. ICSS measures the effects of drugs on operant responding for electrical stimulation of several brain regions, particularly the medial forebrain bundle (MFB). The MFB carries ascending dopaminergic projections from the ventral tegmental area (VTA) to targets in the nucleus accumbens (NAc) and prefrontal cortex (PFC), as well as descending glutamatergic and GABAergic fibers to the midbrain [5]. Stimulation of the MFB is potently reinforcing [8] and enhances dopamine release in terminal fields [9]. Drugs of abuse, especially psychomotor stimulants, reduce the amount of stimulation required to sustain responding, as measured by the stimulation frequency that supports half-maximal responding (EF50) or the brain stimulation reward (BSR) threshold, $\theta_{0}[7,10,11]$.

(C) 2012 Elsevier B.V. All rights reserved.

Correspondence: C.J. Malanga, M.D., Ph.D. Department of Neurology University of North Carolina at Chapel Hill 170 Manning Dr., CB 7025 Chapel Hill, NC 27599-7025 Tel: (919) 966-1683 Fax: (919) 843-4576 malangacj@ neurology.unc.edu.

Publisher's Disclaimer: This is a PDF file of an unedited manuscript that has been accepted for publication. As a service to our customers we are providing this early version of the manuscript. The manuscript will undergo copyediting, typesetting, and review of the resulting proof before it is published in its final citable form. Please note that during the production process errors may be discovered which could affect the content, and all legal disclaimers that apply to the journal pertain.

Conflicts of interest: None. 
In these studies, we investigated the behavioral effects of mephedrone in C57BL/6J mice using ICSS. While previous studies have examined mephedrone pharmacology and patterns of misuse in human populations (reviewed in [12]), the behavioral effects of mephedrone have been largely unexplored in rodents. BSR threshold, EF50, and maximum response rates were determined in C57BL/6J mice before and after treatment with mephedrone, cocaine, or saline vehicle to test the hypothesis that mephedrone would potentiate brain stimulation reward similarly to the psychostimulant cocaine.

\section{MATERIALS AND METHODS}

2.1. Mice

Male C57BL/6J mice ( $\mathrm{n}=6$; Jackson Laboratories, Bar Harbor, ME) weighing at least $25 \mathrm{~g}$ were housed individually in polycarbonate cages $(28 \times 17 \times 14 \mathrm{~cm})$ with food and water freely available through wire lids. Cob-bedding was changed weekly, and the vivarium was $21^{\circ} \mathrm{C}$ with a 12 hour light cycle (lights on at 8:00 PM). Procedures, approved by the University of North Carolina Institutional Animal Care and Use Committee (IACUC), were conducted according to the Guide for the Care and Use of Laboratory Animals (NIH publication No. 85-23, revised 2011) between 8:30 AM and 12:30 PM.

\subsection{Surgery}

Under ketamine (120 mg/kg) and xylazine (18 mg/kg) (Sigma, St Louis, MO) anesthesia, mice were stereotaxically implanted with insulated monopolar stainless steel electrodes ( $0.28 \mathrm{~mm}$ diameter, Plastics One, Roanoke, VA) aimed at the right medial forebrain bundle at the level of the lateral hypothalamus (coordinates relative to bregma: AP $-1.2 \mathrm{~mm}, \mathrm{ML}$ $-1.0 \mathrm{~mm}, \mathrm{DV}-5.0 \mathrm{~mm}$ ) [13], grounded to a stainless steel skull screw and secured to the skull with dental cement.

\subsection{Intracranial Self-Stimulation}

ICSS experiments were performed as previously described $[14,15]$ in sound-attenuating chambers $(16 \times 14 \times 13$ in, MedAssociates, St Albans, VT) containing operant conditioning boxes with a grid floor (ENV-005A; MedAssociates), wheel manipulandum (ENV-113AM; MedAssociates) and house light (ENV-315W; MedAssociates). MED-PC software for Windows (v4.1; MedAssociates) controlled electrical stimulation (500 ms train of unipolar cathodal square-wave current $100 \mu \mathrm{s}$ pulses and a trial-dependent frequency) through a stimulator (PHM-150B/2; MedAssociates) connected to a swivel commutator and insulated wire (Plastics One, Roanoke, VA) attached to the stimulating electrode. Each response (1 response $=1 / 4$ turn of the wheel manipulandum) activated the house light and produced a stimulation. During the $500 \mathrm{~ms}$ stimulation period, wheel responses were recorded but did not earn additional stimulation.

Mice were initially conditioned to respond for brain stimulation reward (BSR) at a single stimulus intensity and frequency, after which stimulus intensity remained constant for each mouse. Mice were subsequently trained to respond for 15 decreasing stimulation frequencies ( $0.05 \log _{10}$ steps) presented in three series. Each frequency was available for 50 seconds and separated by a 10 -second timeout in which 5 non-contingent priming stimulations were delivered. For each response series, the maximum response rate was measured, and the frequency that maintains half-maximal responding (EF50) and sustains responding (BSR threshold or $\theta_{0}$ ) were estimated through least squares regression. Daily baseline values were calculated from responses during the second and third series. When ICSS responding was stabilized, the mice were tested for the effects of mephedrone $(1.0,3.0,10.0 \mathrm{mg} / \mathrm{kg}$ or saline i.p.) or cocaine $(1.0,3.0,10.0 \mathrm{mg} / \mathrm{kg}$ or saline i.p.). After baseline responding, the mice were removed from the conditioning chambers, injected with drug, and returned immediately for 
four 15-minute response series (i.e. 60 minutes of testing). Post-injection ICSS measures were expressed as a percentage of the pre-injection baseline on that day.

\subsection{Histology}

At the end of the experiment, $50 \mu \mathrm{m}$ coronal brain sections were collected from each mouse following anesthesia with sodium pentobarbital $(120 \mathrm{mg} / \mathrm{kg}$ i.p.) and intracardiac perfusion with $0.9 \%$ saline followed by $4 \%$ paraformaldehyde in $0.1 \mathrm{M}$ phosphate buffered saline. Sections were stained with cresyl violet for Nissl, and electrode locations were confirmed by direct microscopic visualization. One mouse died before the end of the study, and electrode placements were unavailable for this subject.

\subsection{Drugs}

Mephedrone (4-methylmethcathinone; generously provided by Dr. Michael Taffe, Scripps Research Institute, La Jolla, CA) and cocaine (Sigma) were dissolved in $0.9 \%$ saline and injected intraperitoneally through a 27 -gauge needle in a volume of $1 \mathrm{ml} / 100 \mathrm{~g}$ body weight. Drug doses were given in a random order that alternated every other day with saline injections. Each drug dose was given twice and its effects on ICSS measures were averaged for each mouse. Only behavioral data from mice that received all drug doses were included in analyses of each drug effect. All experiments involving mephedrone were performed prior to scheduling by the United States Drug Enforcement Agency on October 21, 2011.

\subsection{Data Analysis}

One-way repeated measures analysis of variance (ANOVA) determined the effects of mephedrone and cocaine on measures of ICSS. Bonferroni-corrected post hocs were performed when $\mathrm{p}<0.05$. Paired $\mathrm{t}$-tests were used to compare repeated treatments for each drug dose and response series

\section{RESULTS}

The electrode placements are shown in Figure 1A-B. All 6 mice that were implanted responded for electrical stimulation of the medial forebrain bundle within 2 sessions. Although electrodes were implanted at the AP (skull, relative to bregma) coordinate of -1.3 $\mathrm{mm}$, tip locations varied from -1.06 to $-1.58 \mathrm{~mm}$. The average baseline EF50 and response threshold $\left(\theta_{0}\right)$ in these mice prior to all drug experiments expressed as charge delivery was $-0.31 \pm 0.028 \mu \mathrm{C}$ and $-0.36 \pm 0.036 \mu \mathrm{C}$, respectively. The average baseline maximum response rate prior to all drug experiments was $162 \pm 20.6$ responses/50s. The mice responded in a frequency-dependent manner, and mephedrone and cocaine produced parallel leftward shifts the rate-frequency curves, despite having different effects on maximum response rate (Figure 1C). No significant differences were detected between drug replicates for each drug, dose, and response series.

Mephedrone dose-dependently lowered EF50 (Figure 2) and BSR threshold ( $\theta_{0}$; Figure 3) during the second $\left(F_{3,15}=19.0, p<0.001 ; F_{3,15}=7.4, p=0.003\right.$, respectively $)$, third $\left(F_{3,15}\right.$ $=5.4, p=0.01 ; F_{3,15}=3.7, p=0.04$, respectively $)$, and fourth $\left(F_{3,15}=12.6, p<0.001 ; F_{3,15}\right.$ $=3.7, p=0.03$, respectively) 15 -minute post-injection response series when compared to saline vehicle. There was no significant effect on responding during the first 15-minutes of testing. Post hoc analysis revealed that the $3.0 \mathrm{mg} / \mathrm{kg}$ (i.p.) mephedrone dose significantly lowered EF50 during the second 15-minute post-injection response series, while the 10.0 $\mathrm{mg} / \mathrm{kg}$ dose (i.p.) significantly lowered EF50 during the second, third, and fourth response series. The 3.0 and $10.0 \mathrm{mg} / \mathrm{kg}$ (i.p.) mephedrone dose significantly lowered $\theta_{0}$ during the second 15-minute post-injection response series. 
Cocaine dose-dependently lowered EF50 (Figure 2$)$ and BSR threshold $\left(\theta_{0}\right.$; Figure 3$)$ during the first 15-minute post-injection response series when compared to saline $\left(F_{3,12}=7.1, p=\right.$ $0.005 ; F_{3,12}=6.3, p=0.008$, respectively). Cocaine lowered the EF50, but not BSR threshold, during the second $\left(F_{3,12}=9.0, p=0.002\right)$ and third $\left(F_{3,12}=7.4, p=0.006\right) 15$ minute post-injection response series when compared to saline. These doses did not significantly affect responding during the final 15 minutes of testing. Post hoc analysis revealed that the $3.0 \mathrm{mg} / \mathrm{kg}$ (i.p.) cocaine dose significantly lowered EF50 during the first and second 15-minute post injection series when compared to saline vehicle. The $10.0 \mathrm{mg} /$ $\mathrm{kg}$ (i.p.) cocaine dose significantly lowered EF50 during the first, second, and third response series and lowered the BSR threshold in the first series only.

Mephedrone dose-dependently lowered maximum response rate (Figure 4) during the second 15-minute post-injection response series $\left(F_{3,15}=6.8, p=0.004\right)$; only the $10.0 \mathrm{mg} /$ $\mathrm{kg}$ dose was significantly different from the saline vehicle. Cocaine tended to increase maximum response rate in the first 15-minute response period, but this effect was not significant (Figure 4).

\section{DISCUSSION}

The intracranial self-stimulation (ICSS) method has been used since the 1950's to characterize brain reward system function in rodents [5]. Drugs with abuse potential, regardless of their pharmacological class, potentiate brain stimulation reward (BSR) [7]. Using ICSS, we examined the behavioral effects of the synthetic stimulant mephedrone in C57BL/6J mice and compared them to cocaine. We found that across the dose range tested $\left(1.0,3.0\right.$, and $10.0 \mathrm{mg} / \mathrm{kg}$ i.p.), cocaine and mephedrone both lowered EF50 and $\theta_{0}$ with similar potency. Mephedrone also decreased maximum response rate during the second 15minute response series, while cocaine produced a non-significant trend toward increased maximum response rate during the first 15 minutes of testing. Although the behavioral effects of mephedrone were detected 15 minutes after the effects of cocaine, the duration of action of each drug on measures of ICSS was similar.

In these studies, we used the "curve-shift" method of ICSS to test the behavioral effects of mephedrone and cocaine on brain reward circuitry. During each testing session, mice responded for descending frequencies of brain stimulation, generating characteristic ratefrequency curves. Drugs that potentiate BSR produce a leftward shift in the rate-frequency curve (e.g. cocaine [14]), as evidenced by decreases in the EF50 and $\theta_{0}$. Drugs that devalue BSR (e.g. neuroleptics [16]), produce a rightward shift in the rate-frequency curve and increase the EF50 and $\theta_{0}$. Since drugs are given non-contingently in ICSS, one can use this method to quantify the behavioral effects of a substance on mesocorticolimbic reward circuitry independent of drug consumption. In these experiments, both cocaine and mephedrone produced robust parallel leftward shifts in the rate frequency curve (e.g. Figure 1C), and the magnitude of these effects on EF50 and $\theta_{0}$ was similar for both drugs. The maximum effect of the $10.0 \mathrm{mg} / \mathrm{kg}$ cocaine dose on EF50 and $\theta_{0}$ was $(66.4 \pm 9.4 \% ; 60.1 \pm$ $12.7 \%$ of pre-injection baseline, respectively), while the maximum effect of $10.0 \mathrm{mg} / \mathrm{kg}$ mephedrone dose on EF50 and $\theta_{0}$ was $(72.3 \pm 5.8 \% ; 59.6 \pm 10.9 \%$ of pre-injection baseline, respectively). These results suggest that mephedrone potentiates responding for BSR in C57BL/6J mice similarly to cocaine, which may be indicative of its abuse potential.

Mesocorticolimbic dopamine pathways are a common substrate of drugs of abuse, and involve neurotransmitter release in cortical and subcortical areas, such as the NAc and PFC, by A10 projection neurons in the midbrain VTA. Activation of these pathways is thought to motivate and reinforce drug taking [17]. Mephedrone administration robustly increases activity in the NAc, PFC, and VTA, as measured by c-Fos expression [18], and increases 
extracellular levels of dopamine (DA; 498\%) and serotonin (5-HT; 941\%) in the NAc of awake rats [19]. These effects are most likely due to transporter-mediated efflux of monoamines [20], rather than by re-uptake inhibition, which is the sole mechanism of action of cocaine [21]. Mephedrone displays nanomolar potency for the dopamine transporter (DAT), serotonin transporter (SERT), and norepinephrine transporter (NET) and is similar to 3,4-methylenedioxymethamphetamine (MDMA or "ecstasy") in selectivity and potency [20]. In ICSS, drugs that enhance dopaminergic neurotransmission lower response thresholds [16], while serotoninergic agents have diverse effects on ICSS responding depending on the receptor subclass they target [22]. For example, 5- $\mathrm{HT}_{1 \mathrm{~A}}$ receptor agonists lower thresholds [23], while 5- $\mathrm{HT}_{1 \mathrm{~B}}$ agonists [24], 5- $\mathrm{HT}_{2 \mathrm{C}}$ agonists [25], and the selective serotonin re-uptake inhibitor fluoxetine [23] increase thresholds. MDMA, which produces similar elevations of extracellular DA and 5-HT as mephedrone [19, 20], robustly lowers ICSS thresholds in rats [26]. Although mechanisms underlying the observed effects of mephedrone in these studies are unknown, the enhancement of dopaminergic, as well as serotonergic, neurotransmission in loci associated with positive reinforcement (e.g. NAc) may contribute to the potentiation of BSR by the drug. Future studies using electrophysiological or voltammetric techniques would be required to support this hypothesis.

To date, there have been only a few studies examining the effects of mephedrone on substance abuse-related behaviors in animal models. These methods include drug selfadministration, in which a drug reinforces operant responding, and the conditioned place preference method (CPP), a variant of Pavlovian conditioning in which laboratory animals display preference for previously drug-paired environments. For example, the psychostimulant cocaine, as well as methamphetamine [27] and amphetamine [28], is readily self-administered by $\mathrm{C} 57 \mathrm{BL} / 6 \mathrm{~J}$ mice [27] and produces robust conditioned place preference [29]. Although the behavioral effects of mephedrone have not been investigated in mice using these methods, the drug is intravenously self-administered by Sprague-Dawley rats using a fixed-ratio reinforcement schedule [30]. In planaria, mephedrone induces place preference and causes abstinence-induced withdrawal-like behavior [31]. The current findings, when examined in the context of other behavioral effects of the drug, suggest that mephedrone is a potent reinforcer that requires further behavioral characterization in animal models of drug abuse.

We also observed that mephedrone dose-dependently decreased maximum response rate during the second 15 minutes of testing, while cocaine produced a non-significant trend toward increased maximum response rate during the first 15-minute response period, which has been previously reported in C57BL/6J mice [14]. The curve-shift ICSS method is ratedependent, and therefore maximum response rate provides some information about the psychomotor effects of the drug tested $[10,32]$. It is unlikely that the effects of mephedrone on maximum response rate were due to sedation, however, given that it produces locomotor stimulation in rats $[18,20]$ and mice [33]. Alternatively, mephedrone may have induced behaviors that interfered with operant responding, such as stereotypies, which are observed following MDMA exposure [34]. Most likely, divergent effects of cocaine and mephedrone on maximum operant response rate reflect differences in their mechanism of action. Unlike the monoamine re-uptake inhibitor cocaine, mephedrone produces a robust transportermediated increase in striatal 5-HT levels $[19,20]$, which is associated with reduced ICSS response rate (e.g. following fenfluramine administration [35]). Given that selective DAT blockade by GBR-12909 enhances responding for BSR [36], the effects of cocaine on maximum response rate are likely due to its effects on extracellular dopamine levels. Future studies that further characterize the psychomotor effects of mephedrone in the context of dopaminergic and serotonergic neurotransmission may help explain the observed effect of mephedrone on maximum response rate. 


\section{CONCLUSION}

Recreational use of "bath salts" has increased in recent years, and stimulant abuse represents a significant public health problem. These substances are associated with compulsive drug taking and have dangerous side effects (e.g. neurotoxicity, hyperthermia, seizures, etc.). As of October 21, 2011, mephedrone was temporarily assigned Schedule I status for one year by the United States Drug Enforcement Agency while the United States Department of Health and Human Services investigates whether it should be permanently controlled under the Controlled Substances Act. Schedule I status denotes substances that have a high potential for abuse without having a legitimate therapeutic use [4]. This study examined the ability of acutely administered cocaine and mephedrone to alter responding for electrical stimulation of the medial forebrain bundle using the curve-shift method of ICSS in C57BL/ $6 \mathrm{~J}$ mice. We demonstrate that mephedrone, like cocaine and amphetamines, potentiates brain stimulation reward, which may indicate that it has a high potential for abuse. Future studies will be necessary to fully characterize the cellular and behavioral effects of acute and chronic mephedrone exposure and compare them to more extensively characterized psychostimulants.

\section{Acknowledgments}

We would like to thank Dr. Thomas L. Kash for comments on an earlier version of the manuscript and Dr. Deepshikha Angrish, Dr. Tobin J. Dickerson, and Dr. Michael A. Taffe for providing mephedrone. Support was provided by the UNC Bowles Center for Alcohol Studies and the National Institutes of Health (AA018335 to CJM; AA021312 to JER; DA024105 to MAT).

\section{REFERENCES}

1. Freeman TP, Morgan CJ, Vaughn-Jones J, Hussain N, Karimi K, Curran HV. Cognitive and subjective effects of mephedrone and factors influencing use of a 'new legal high'. Addiction. 2012; 107:792-800. [PubMed: 22257011]

2. Winstock A, Mitcheson L, Ramsey J, Davies S, Puchnarewicz M, Marsden J. Mephedrone: use, subjective effects and health risks. Addiction. 2011; 106:1991-6. [PubMed: 21592252]

3. Maskell PD, De Paoli G, Seneviratne C, Pounder DJ. Mephedrone (4-methylmethcathinone)-related deaths. Journal of analytical toxicology. 35:188-91. [PubMed: 21439157]

4. Fass JA, Fass AD, Garcia AS. Synthetic cathinones (bath salts): legal status and patterns of abuse. Ann Pharmacother. 2012; 46:436-41. [PubMed: 22388331]

5. Wise RA. Forebrain substrates of reward and motivation. J Comp Neurol. 2005; 493:115-21. [PubMed: 16254990]

6. Olds J, Milner P. Positive reinforcement produced by electrical stimulation of septal area and other regions of rat brain. J Comp Physiol Psychol. 1954; 47:419-27. [PubMed: 13233369]

7. Kornetsky C, Bain G. Brain-stimulation reward: a model for the study of the rewarding effects of abused drugs. NIDA Res Monogr. 1992; 124:73-93. [PubMed: 1470216]

8. Valenstein ES, Campbell JF. Medial forebrain bundle-lateral hypothalamic area and reinforcing brain stimulation. Am J Physiol. 1966; 210:270-4. [PubMed: 5901463]

9. Kuhr WG, Wightman RM, Rebec GV. Dopaminergic neurons: simultaneous measurements of dopamine release and single-unit activity during stimulation of the medial forebrain bundle. Brain Res. 1987; 418:122-8. [PubMed: 3499205]

10. Carlezon WA Jr. Chartoff EH. Intracranial self-stimulation (ICSS) in rodents to study the neurobiology of motivation. Nat Protoc. 2007; 2:2987-95. [PubMed: 18007634]

11. Gallistel CR, Freyd G. Quantitative determination of the effects of catecholaminergic agonists and antagonists on the rewarding efficacy of brain stimulation. Pharmacol Biochem Behav. 1987; 26:731-41. [PubMed: 3602032] 
12. Schifano F, Albanese A, Fergus S, Stair JL, Deluca P, Corazza O, et al. Mephedrone (4methylmethcathinone; 'meow meow'): chemical, pharmacological and clinical issues. Psychopharmacology (Berl). 2011; 214:593-602. [PubMed: 21072502]

13. Franklin, KBJ.; Paxinos, G. The mouse brain in stereotaxic coordinates. 3rd ed.. Elsevier/ Academic Press; Amsterdam: New York: 2008.

14. Fish EW, Riday TT, McGuigan MM, Faccidomo S, Hodge CW, Malanga CJ. Alcohol, cocaine, and brain stimulation-reward in C57B16/J and DBA2/J mice. Alcohol Clin Exp Res. 2010; 34:819. [PubMed: 19860803]

15. Robinson JE, Fish EW, Krouse MC, Thorsell A, Heilig M, Malanga CJ. Potentiation of brain stimulation reward by morphine: effects of neurokinin-1 receptor antagonism. Psychopharmacology (Berl). 2012; 220:215-24. [PubMed: 21909635]

16. Nakajima S, O'Regan NB. The effects of dopaminergic agonists and antagonists on the frequencyresponse function for hypothalamic self-stimulation in the rat. Pharmacol Biochem Behav. 1991; 39:465-8. [PubMed: 1682950]

17. Wise RA, Rompre PP. Brain dopamine and reward. Annu Rev Psychol. 1989; 40:191-225. [PubMed: 2648975]

18. Motbey CP, Hunt GE, Bowen MT, Artiss S, McGregor IS. Mephedrone (4-methylmethcathinone, 'meow'): acute behavioural effects and distribution of Fos expression in adolescent rats. Addict Biol. 2012; 17:409-22. [PubMed: 21995495]

19. Kehr J, Ichinose F, Yoshitake S, Goiny M, Sievertsson T, Nyberg F, et al. Mephedrone, compared with MDMA (ecstasy) and amphetamine, rapidly increases both dopamine and 5-HT levels in nucleus accumbens of awake rats. Br J Pharmacol. 2011; 164:1949-58. [PubMed: 21615721]

20. Baumann MH, Ayestas MA Jr. Partilla JS, Sink JR, Shulgin AT, Daley PF, et al. The Designer Methcathinone Analogs, Mephedrone and Methylone, are Substrates for Monoamine Transporters in Brain Tissue. Neuropsychopharmacology. 2012; 37:1192-203. [PubMed: 22169943]

21. Ritz MC, Lamb RJ, Goldberg SR, Kuhar MJ. Cocaine receptors on dopamine transporters are related to self-administration of cocaine. Science. 1987; 237:1219-23. [PubMed: 2820058]

22. Hayes DJ, Greenshaw AJ. 5-HT receptors and reward-related behaviour: a review. Neurosci Biobehav Rev. 2011; 35:1419-49. [PubMed: 21402098]

23. Harrison AA, Markou A. Serotonergic manipulations both potentiate and reduce brain stimulation reward in rats: involvement of serotonin-1A receptors. J Pharmacol Exp Ther. 2001; 297:316-25. [PubMed: 11259559]

24. Hayes DJ, Graham DA, Greenshaw AJ. Effects of systemic 5-HT(1B) receptor compounds on ventral tegmental area intracranial self-stimulation thresholds in rats. Eur J Pharmacol. 2009; 604:74-8. [PubMed: 19135047]

25. Hayes DJ, Clements R, Greenshaw AJ. Effects of systemic and intra-nucleus accumbens 5-HT2C receptor compounds on ventral tegmental area self-stimulation thresholds in rats. Psychopharmacology (Berl). 2009; 203:579-88. [PubMed: 19031071]

26. Hubner CB, Bird M, Rassnick S, Kornetsky C. The threshold lowering effects of MDMA (ecstasy) on brain-stimulation reward. Psychopharmacology (Berl). 1988; 95:49-51. [PubMed: 2898790]

27. Carney JM, Landrum RW, Cheng MS, Seale TW. Establishment of chronic intravenous drug selfadministration in the C57BL/6J mouse. Neuroreport. 1991; 2:477-80. [PubMed: 1912483]

28. Elmer GI, Pieper JO, Hamilton LR, Wise RA. Qualitative differences between C57BL/6J and DBA/2J mice in morphine potentiation of brain stimulation reward and intravenous selfadministration. Psychopharmacology (Berl). 2010; 208:309-21. [PubMed: 20013116]

29. Miner LL. Cocaine reward and locomotor activity in C57BL/6J and $129 / \mathrm{SvJ}$ inbred mice and their F1 cross. Pharmacol Biochem Behav. 1997; 58:25-30. [PubMed: 9264065]

30. Hadlock GC, Webb KM, McFadden LM, Chu PW, Ellis JD, Allen SC, et al. 4Methylmethcathinone (mephedrone): neuropharmacological effects of a designer stimulant of abuse. J Pharmacol Exp Ther. 2011; 339:530-6. [PubMed: 21810934]

31. Ramoz L, Lodi S, Bhatt P, Reitz AB, Tallarida C, Tallarida RJ, et al. Mephedrone ("bath salt") pharmacology: insights from invertebrates. Neuroscience. 2012; 208:79-84. [PubMed: 22300981]

32. Miliaressis E, Rompre PP, Laviolette P, Philippe L, Coulombe D. The curve-shift paradigm in selfstimulation. Physiol Behav. 1986; 37:85-91. [PubMed: 3016774] 
33. Angoa-Perez M, Kane MJ, Francescutti DM, Sykes KE, Shah MM, Mohammed AM, et al. Mephedrone, an abused psychoactive component of 'bath salts' and methamphetamine congener, does not cause neurotoxicity to dopamine nerve endings of the striatum. J Neurochem. 2012; 120:1097-107. [PubMed: 22191803]

34. Baumann MH, Clark RD, Rothman RB. Locomotor stimulation produced by 3,4methylenedioxymethamphetamine (MDMA) is correlated with dialysate levels of serotonin and dopamine in rat brain. Pharmacol Biochem Behav. 2008; 90:208-17. [PubMed: 18403002]

35. Olds ME, Yuwiler A. Effects of acute and chronic fenfluramine on self-stimulation and its facilitation by amphetamine. Eur J Pharmacol. 1992; 216:363-72. [PubMed: 1425928]

36. Phillips AG, Blaha CD, Fibiger HC. Neurochemical correlates of brain-stimulation reward measured by ex vivo and in vivo analyses. Neurosci Biobehav Rev. 1989; 13:99-104. [PubMed: 2530478] 


\section{Research Highlights}

- Mephedrone and cocaine similarly affected ICSS responding in C57BL/6J mice.

- Both drugs decreased the EF50 and BSR threshold $\left(\theta_{0}\right)$.

- $10.0 \mathrm{mg} / \mathrm{kg}$ mephedrone (i.p.) lowered maximum operant response rate.

- Mephedrone had a slower onset of action than cocaine. 


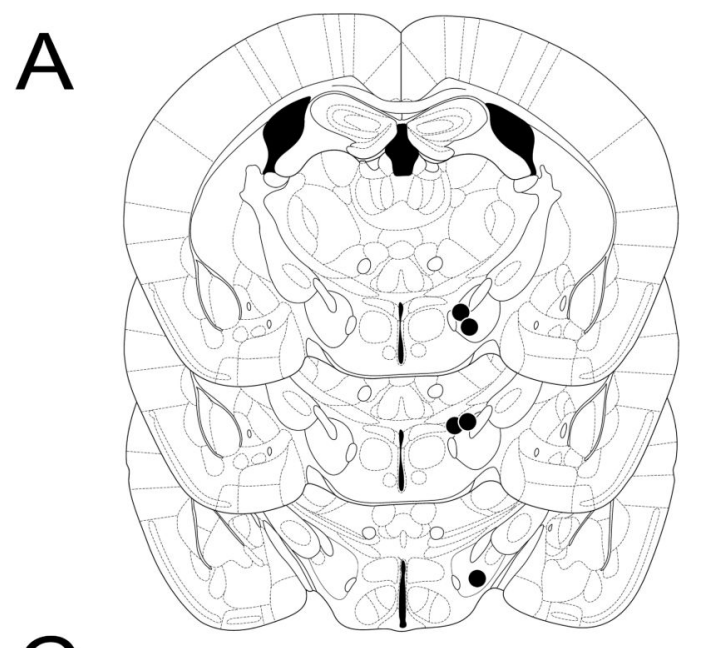

C

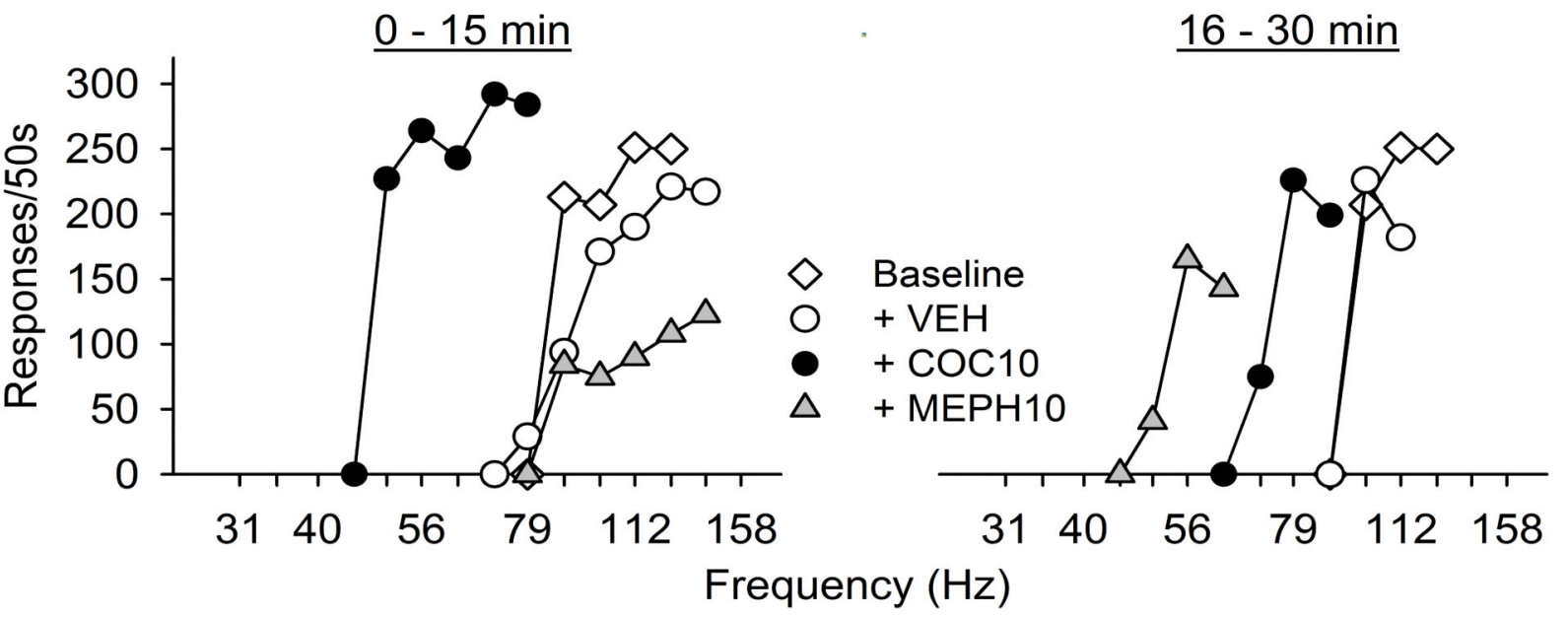

Figure 1.

Placement of intracranial self-stimulation monopolar electrodes (Panels A-B) and representative rate-frequency curves (Panel C) in C57BL/6J mice. Electrodes were aimed at the right medial forebrain bundle at the level of the lateral hypothalamus. Black circles represent the most ventral position of the electrode tip (Panel A) as detected by visual inspection of Nissl stained brain sections using light microscopy (Panel B). Panel C depicts responding for different frequencies of brain stimulation reward by an individual C57BL/6J mouse. These rate-frequency curves depict the effects of saline vehicle (i.p.; white circles), $10.0 \mathrm{mg} / \mathrm{kg}$ cocaine (i.p.; black circles), and $10.0 \mathrm{mg} / \mathrm{kg}$ mephedrone (i.p.; gray triangles) during the first $(0-15 \mathrm{~min})$ and second $(16-30)$ post-injection response period following a baseline determination (white diamonds). 


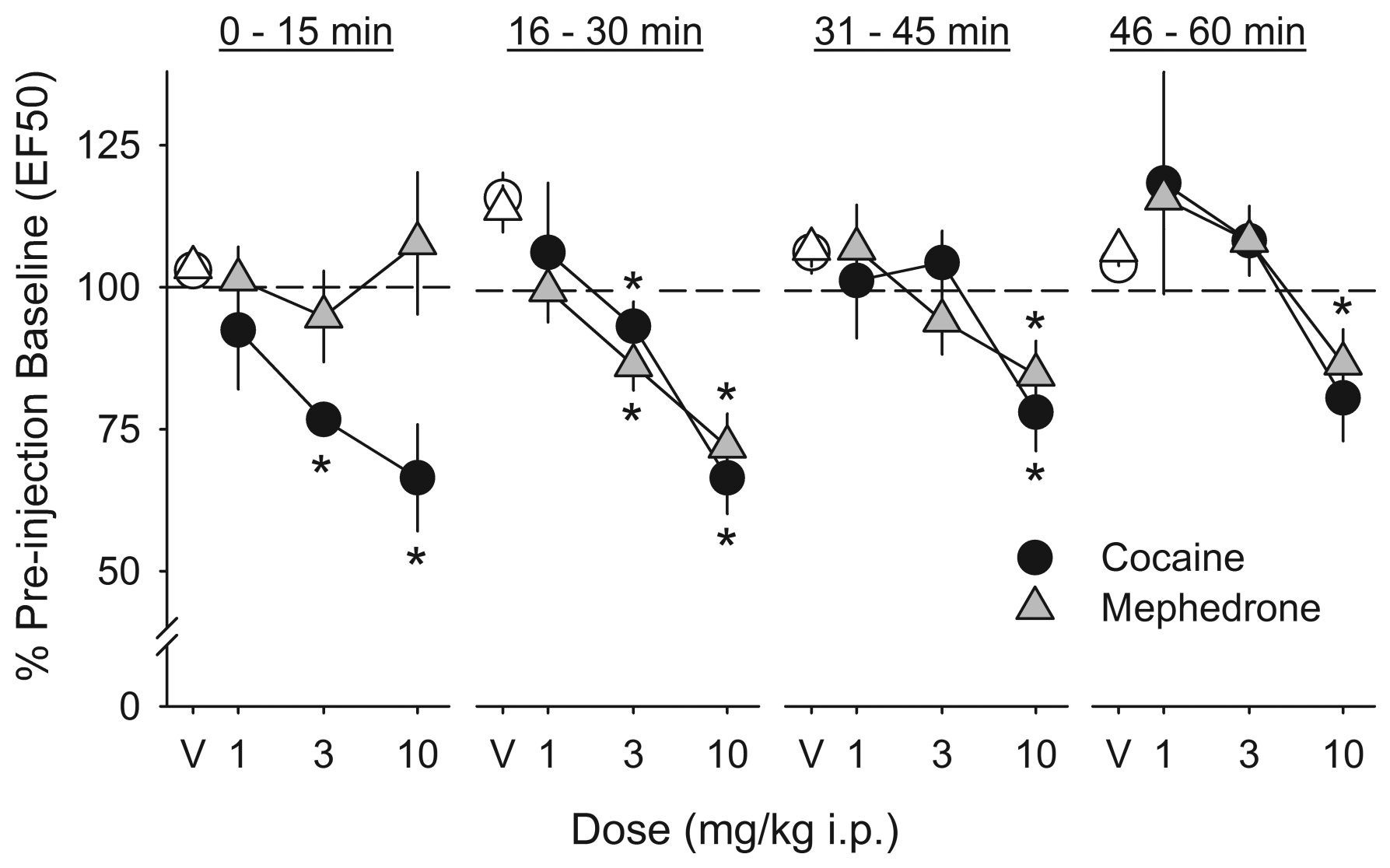

Figure 2.

Dose-response relationship for the effects of mephedrone and cocaine on the frequency that supported half-maximal responding (EF50) in C57BL/6J mice. EF50 was measured before and after intraperitoneal injection with saline vehicle (white symbols), mephedrone (1.0, 3.0, and $10.0 \mathrm{mg} / \mathrm{kg}$, i.p.; gray triangles; $\mathrm{n}=6)$, or cocaine $(1.0,3.0$, and $10.0 \mathrm{mg} / \mathrm{kg}$, i.p.; black circles; $\mathrm{n}=5$ ). Results are presented as mean percentage of pre-injection baseline during four 15-minute post-injection response series (0-15, 16-33, 31-45, and 46-60 minutes postinjection $) \pm$ S.E.M. Asterisks indicate significance $(p<0.05)$ vs. saline vehicle. 


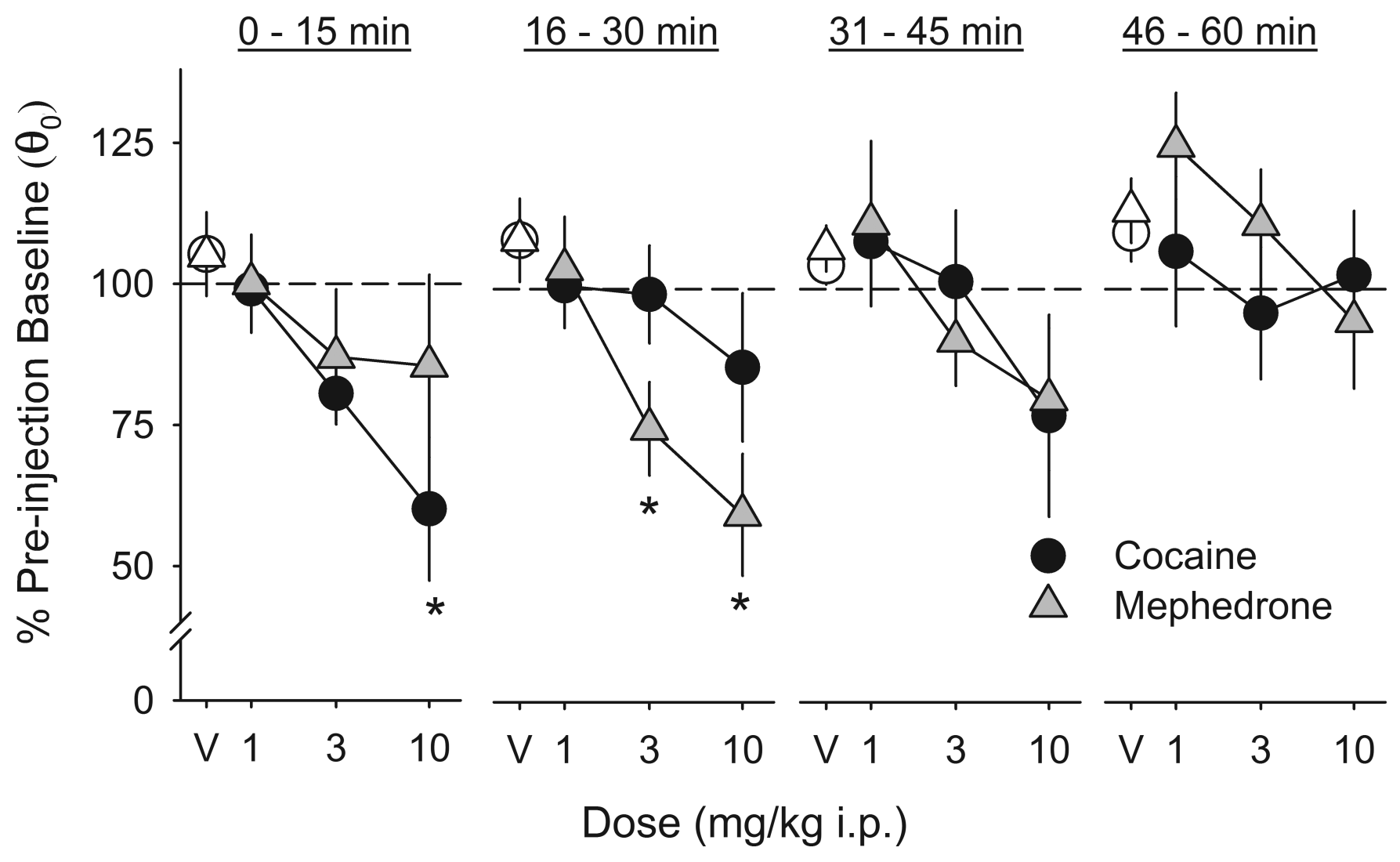

Figure 3.

Dose-response relationship for the effects of mephedrone and cocaine on the brain stimulation reward threshold $\left(\theta_{0}\right)$ in C57BL/6J mice. $\theta_{0}$ was measured before and after intraperitoneal injection with saline vehicle (white symbols), mephedrone (1.0, 3.0, and 10.0 $\mathrm{mg} / \mathrm{kg}$, i.p.; gray triangles; $\mathrm{n}=6)$, or cocaine $(1.0,3.0$, and $10.0 \mathrm{mg} / \mathrm{kg}$, i.p.; black circles; $\mathrm{n}$ $=5$ ). Results are presented as mean percentage of pre-injection baseline during four 15 minute post-injection response series (0-15, 16-33, 31-45, and 46-60 minutes post-injection) \pm S.E.M. Asterisks indicate significance $(p<0.05)$ vs. saline vehicle. 


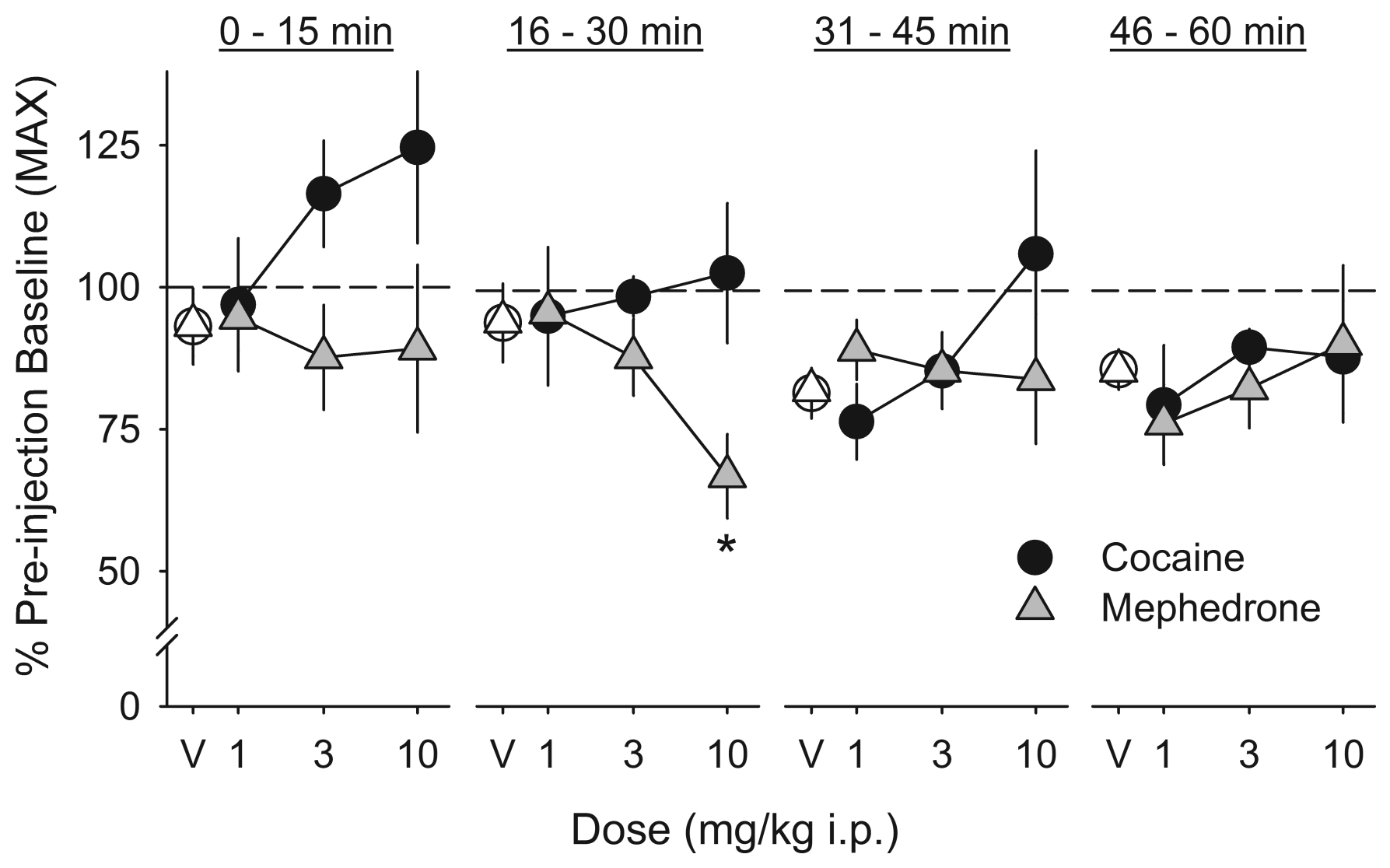

Figure 4.

Dose-response relationship for the effects of mephedrone and cocaine on the maximum response rate (MAX) in C57BL/6J mice. Maximum response rate was measured before and after intraperitoneal injection with saline vehicle (white symbols), mephedrone (1.0, 3.0, and $10.0 \mathrm{mg} / \mathrm{kg}$, i.p.; gray triangles; $\mathrm{n}=6)$, or cocaine $(1.0,3.0$, and $10.0 \mathrm{mg} / \mathrm{kg}$, i.p.; black circles, $\mathrm{n}=5)$. Results are presented as mean percentage of pre-injection baseline during four 15-minute post-injection response series (0-15, 16-33, 31-45, and 46-60 minutes postinjection $) \pm$ S.E.M. Asterisks indicate significance $(p<0.05)$ vs. saline vehicle. 